\title{
Simulating Particulate Organic Advection along Bottom Slopes to Improve Simulation of Estuarine Hypoxia and Anoxia
}

\author{
Ping Wang ${ }^{1}$ and Lewis C. Linker ${ }^{2}$ \\ ${ }^{1}$ University of Maryland Center for Environmental Science, Chesapeake Bay Program, \\ 410 Severn Avenue, Annapolis, MD 21403, USA \\ pwang@chesapeakebay. net \\ ${ }^{2}$ US Environmental Protection Agency/CBPO, 410 Severn Ave., Suite 109, \\ Annapolis, MD 21403, USA \\ linker. lewis@epa.gov
}

\begin{abstract}
In a coupled hydrodynamic and water quality model, the hydrodynamic model provides forces for movement of simulated particles in the water quality model. A proper simulation of organic solid movement from shallow to deep waters is important to simulate summer hypoxia in the deepwater. It is necessary to have a full blown particle transport model that focuses organic particulates' resuspension and transport. This paper presents an approach to move volatile solids from the shoals to the channel by simulating movement of particulate organics due to slopes based on an example in the Chesapeake Bay eutrophication model. Implementations for the simulation of this behavior in computer parallel processing are discussed.
\end{abstract}

Keywords: hydrodynamic model, estuarine model, movement along slope, particulate organic transport, parallel processing.

\section{Introduction}

The Chesapeake Bay Estuarine (Water Quality and Sediment Transport) Model is designed to simulate the current estuarine eutrophication in the Chesapeake and to examine nutrient and sediment reductions to restore water quality [1]. It simulates algal blooms due to excessive nutrient inputs, and the subsequent decay of organics and reduction in dissolved oxygen in deep water, particularly in the middle channel of the main-stem Bay and tidal tributaries in the summer. Volatile, or reactive organics in the Bay are in dissolved and particulate forms and the particulate organics are also referred to as volatile solids or volatile suspended solids. We propose that volatile solids deposition to the channel bed come from other areas of the estuary, including the near-shore shallow waters, other then solely algal production and settling in the water column overlying the deep channel $[2,3]$. This is based on the observation that a simple mass balance of the algal production over the deep channel of the mainstem Chesapeake is insufficient for generation of the observed anoxia in the deep water. 
The Water Quality and Sediment Transport Model is coupled with the Estuarine Hydrodynamic Model [4] which provides forcing for particle transport in water columns. The hydrodynamic model also provides bottom shears stress for the simulation of scour and resuspension of sediment from bed. Besides movement due to hydrodynamic forces, sediment can also sink down and move along bed slope due to gravity [5]. The Chesapeake Bay Estuarine Model assigned settling velocities to simulate sinking from upper model cells toward sediment beds for different sediment classes, however without considering movement along bed slope [6]. The resuspension due to bottom shear is under development for inorganic solids, while the resuspension for organic solids are only partially simulated by reducing net settling rates based on model calibration. In this context, once organic solids settle on bed, they will no-longer be scoured or resuspended. This causes insufficient transport of organic solids from shallow to deep waters and causes insufficient oxygen demand to simulate the observed anoxia and hypoxia. A remedy to this in the earlier phase of model, i.e., with a grid of 13,000 cells [6], was by adjusting some parameters through model calibration that yielded reasonable simulation of dissolved oxygen (DO) as shown in Figure 1. The circle symbols are observed DO and the dots are simulated DO in the 13,000-cell model. However, as the model grid was refined by an order of magnitude to the current 57,000 cells many shallow water and shoal cells became less connected with deep water and the adjusted parameters in the old model calibration became less optimal, as pointed out by Michael Kemp of the University of Maryland Center for Environmental Science (personal communication) and illustrated by Figure 2. Here we assume that the coarse grid has two cells horizontally, from the right shoal to the channel (Figure 2a); while the finer grid has four cells horizontally (Figure 2b). The materials from the areas of downward arrows can reach the channel bottom cell (letters A and B) more easily for the coarser grid than for the finer grid. This is one of the reasons causing insufficient organic material delivered to deep waters. Even the new refined grid model tried to optimize the same parameters as those in the coarse grid, the calibration of oxygen demand in deep waters is degraded [7]. The plus symbols in Fig. 1 represent the DO simulation in the refined 57,000 cell model.

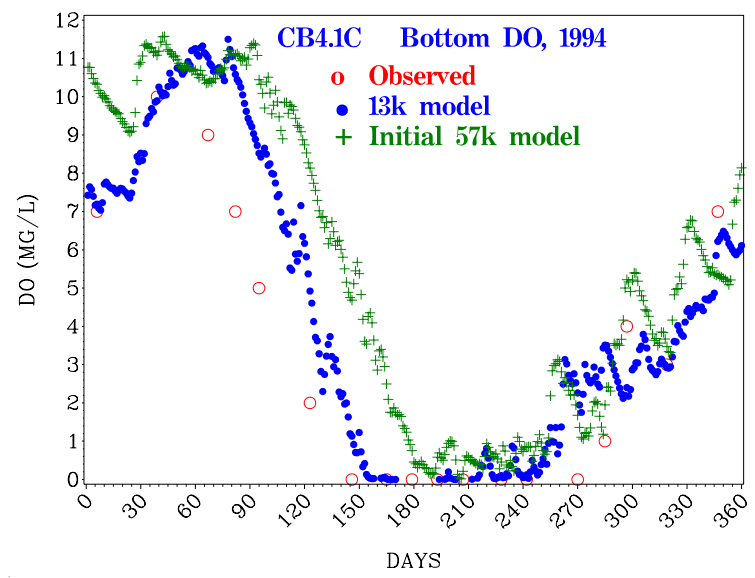

Fig. 1. DO simulations in a coarse grid model (13k grid) and after grid refinement (57k grid) 
a)

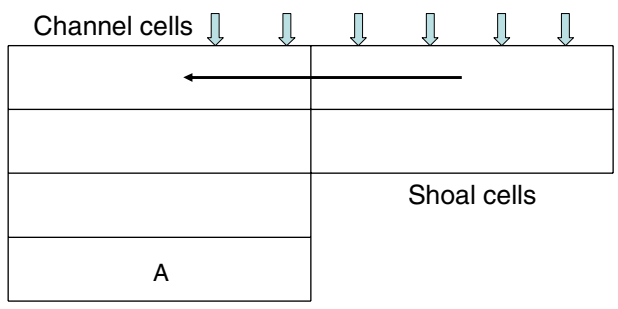

b)

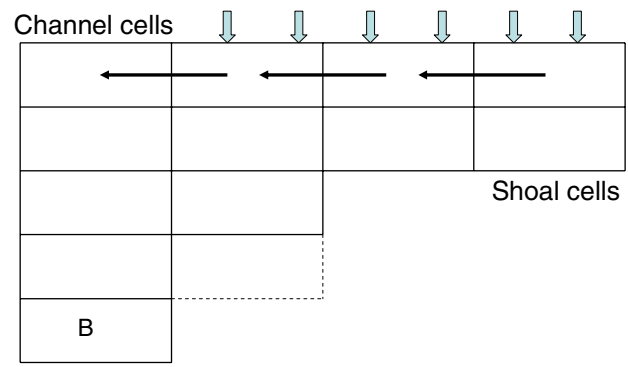

Fig. 2. Schematic coarser (a) and finer (b) grids, showing differences in potential receiving materials from the surface (the downward block-arrows) by channel bed cells (A and B) of the two grids: Cell A of the coarser grid has more chance to receive input materials than Cell $\mathrm{B}$ of the finer grid

In general, if a model simulates well on major mechanisms, a refinement of grid would improve simulation. The degradation after grid refinement may be due to the model discounts some important mechanisms which cannot be simulated well by some adjusted parameters used in the initial coarse grid. This paper explores a method to simulate one of the missing mechanisms, i.e., movement of volatile solids along slopes, so that to better simulate volatile solid movement and oxygen demand in channel for the Chesapeake Bay Estuarine Model.

\section{Method}

\subsection{Basic Model}

The Chesapeake Bay Estuarine Model, a coupled 3-dimensional finitedifference/finite-volume CH3D Hydrodynamic Model and CE-QUAL-ICM Water Quality Model, is used. The model grid uses the Z-grid structure. In this paper, the implementation of slope movement for model is based on the refined $57 \mathrm{k}$ grid.

Daily loads to the model were provided by the Chesapeake Bay Watershed Model. The water quality model simulates major nutrient cycles, including algal growth and decay, involving 36 state variables. Particle movement in the water is controlled by hydrodynamic forces of advection. The CH3D Hydrodynamic Model simulates physical processes impacting estuarine circulation and vertical mixing, that includes tides, freshwater inflows, wind, density effect by salinity and temperature, turbulence, and the Coriolis effect [8]. The basic equations are: 


$$
\begin{gathered}
\partial \mathrm{u} / \partial \mathrm{x}+\partial \mathrm{v} / \partial \mathrm{y}+\partial \mathrm{w} / \partial \mathrm{z}=0 \\
\partial \mathrm{u} / \partial \mathrm{t}+\partial \mathrm{u}^{2} / \partial \mathrm{x}+\partial \mathrm{uv} / \partial \mathrm{y}+\partial \mathrm{uw} / \partial \mathrm{z}=\mathrm{f} \mathrm{v}-1 / \rho \partial \mathrm{P} / \partial \mathrm{x}+\partial\left[\mathrm{A}_{\mathrm{H}} \partial \mathrm{u} / \partial \mathrm{x}\right] / \partial \mathrm{x}+ \\
\partial\left[\mathrm{A}_{\mathrm{H}} \partial \mathrm{u} / \partial \mathrm{y}\right] / \partial \mathrm{y}+\partial\left[\mathrm{A}_{\mathrm{V}} \partial \mathrm{u} / \partial \mathrm{z}\right] / \partial \mathrm{z} \\
\partial \mathrm{v} / \partial \mathrm{t}+\partial \mathrm{v}^{2} / \partial \mathrm{y}+\partial \mathrm{uv} / \partial \mathrm{x}+\partial \mathrm{vw} / \partial \mathrm{z}=-\mathrm{fu}-1 / \rho \partial \mathrm{P} / \partial \mathrm{y}+\partial\left[\mathrm{A}_{\mathrm{H}} \partial \mathrm{v} / \partial \mathrm{x}\right] / \partial \mathrm{x}+ \\
\partial\left[\mathrm{A}_{\mathrm{H}} \partial \mathrm{v} / \partial \mathrm{y}\right] / \partial \mathrm{y}+\partial\left[\mathrm{A}_{\mathrm{V}} \partial \mathrm{v} / \partial \mathrm{z}\right] / \partial \mathrm{z} \\
\partial \mathrm{P} / \partial \mathrm{z}=-\rho \mathrm{g}
\end{gathered}
$$

where, $(\mathrm{u}, \mathrm{v}, \mathrm{w})=$ velocities in $(\mathrm{x}, \mathrm{y}, \mathrm{z})$ directions, $\mathrm{t}=$ time, $\mathrm{f}=$ Coriolis parameter, $\rho=$ density, $\mathrm{P}=$ pressure, $\mathrm{A}_{\mathrm{H}}=$ horizontal turbulent, $\mathrm{A}_{\mathrm{V}}=$ vertical turbulent, and $\mathrm{g}=$ gravitational acceleration.

For sediment material, $\mathrm{S}$, to transport:

$$
\begin{aligned}
\partial \mathrm{S} / \partial \mathrm{t}+\partial \mathrm{uS} / / \partial \mathrm{x}+\partial \mathrm{vS} / \partial \mathrm{y}+ & \partial \mathrm{wS} / \partial \mathrm{z}=\partial\left[\mathrm{K}_{\mathrm{H}} \partial \mathrm{S} / \partial \mathrm{x}\right] / \partial \mathrm{x}+\partial\left[\mathrm{K}_{\mathrm{H}} \partial \mathrm{S} / \partial \mathrm{y}\right] / \partial \mathrm{y} \\
& +\partial\left[\mathrm{K}_{\mathrm{V}} \partial \mathrm{S} / \partial \mathrm{z}\right] / \partial \mathbf{z}
\end{aligned}
$$

where, $\mathrm{K}_{\mathrm{H}}=$ eddy coefficient for horizontal turbulent, and $\mathrm{K}_{\mathrm{V}}=$ eddy coefficient for vertical turbulent. The vertical turbulence is handled by using the concept of eddy viscosity and diffusivity to represent the velocity and density correlation terms. They are computed from main flow characteristics using a method developed by Donaldson [9] and Sheng [10].

Besides the transport, settling of volatile solids in the water column is calculated:

$$
\partial \mathrm{S} / \partial \mathrm{t}=[\text { transport by hydrodynamic forces }]+\mathrm{S}_{\mathrm{U}}(\mathrm{W} / \mathrm{dz})-\mathrm{S}(\mathrm{W} / \mathrm{dz})
$$

where, $\mathrm{S}_{\mathrm{U}}=$ solid in a cell above, $\mathrm{W}=$ settling velocity in water column, and $\mathrm{dz}=$ cell thickness.

Since the resuspension of volatile solid by bottom shears stress is not simulated, a remedy is set for the cells that interface the bed sediment: use net settling velocity, Wnet, which is after a subtraction from the settling velocity (W) to account for the unsimulated resuspension. The Wnet is obtained empirically through model calibration. Thus, the volatile solid in the bottom cell is calculated by:

$$
\partial \mathrm{S} / \partial \mathrm{t}=[\text { transport by hydrodynamic forces }]+\mathrm{S}_{\mathrm{U}}(\mathrm{W} / \mathrm{dz})-\mathrm{S}(\mathrm{Wnet} / \mathrm{dz})
$$

The movement of materials in water columns is through the faces connecting model cells. In a $\Sigma$-grid, bottom cells are connected with vertical faces. While in a Z-grid, bottom cells are not always connected. There, cells among layers are divided by horizontal faces (Fig. 2), including the bottom face of bottom cells even there is slope on bed (as the bold curves in Figure 3). The grid uses a different number of layers to represent different water depths. Particle transport by hydrodynamic forces from a bottom cell (e.g., A) to another bottom cell (e.g., C) in the adjacent water column where there is a layer difference as in this example, the particle will first go parallel to the adjacent cell of the same layer (e.g., B) through a vertical face, then move downward to the bottom cell through a horizontal face (as by the line-arrows $a->b->c)$. 


\subsection{Adding Movement along Slopes}

The initial Chesapeake Bay Water Quality Model does not simulate movement of volatile organic solids along bottom slopes. We add an additional simulation of particulate organic movement along bottom slopes besides their movement by hydrodynamic forces.

We need to connect bottom cells and determine slope directions. This task is easier to implement in a $\Sigma$-grid, since the bottom cells are physically connected.

In a Z-grid the bottom cells are not always physically connected by their faces. The movement along slopes among bottom cells (star symbol in Figure 3 ) is through direct links, as shown by the block-arrows in Figure 3. In order to implement movement along the bottom slopes in a Z-grid we need to set up computationally an image of the bottom to surface cells. Surface cells are in the same layer and are always connected. The looping computation of solid movement among bottom cells can use the linkages among their counterpart surface cells' image. Nevertheless, for the transport in water columns among bottom cells, materials still need to go the "detour" routes (Fig. 3, line-arrows).

The degrees of slope angles affect the movement along slopes. The angle of slope $(\alpha)$ can be determined from the distance between centers of two adjacent cells (c) and their bathymetry difference (d): $\alpha=\tan ^{-1}(\mathrm{~d} / \mathrm{c})$.

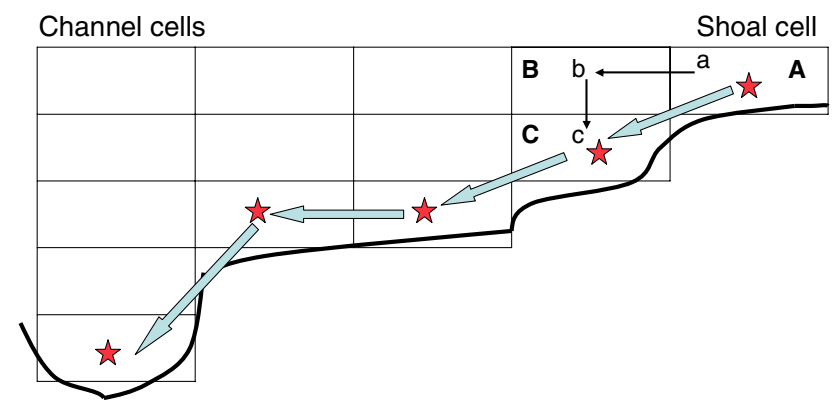

Fig. 3. Schematic graph showing transport simulation among bottom cells in a z-grid. Note: Letters a, b, c with line-arrows are the hydrodynamic movements from cell A to cell $\mathrm{C}$. The movement along slopes among bottom cells (stars) can be implemented through direct links by the block-arrows, which was not simulated by the existing model.

The weight of a solid particle, minus its buoyancy, is the net downward force, $\mathrm{f}_{1}=$ $\mathrm{m}^{*} \mathrm{~g}-\mathrm{b}$, where $\mathrm{m}$ is mass of solid, $\mathrm{g}$ is gravitational acceleration, $\mathrm{b}$ is buoyancy $=$ $(\mathrm{m} / \rho s)^{*} \rho \mathrm{w}^{*} \mathrm{~g},=\mathrm{m}^{*} \mathrm{~g} * \rho \mathrm{w} / \rho \mathrm{s}, \rho \mathrm{w}$ is density of water, and $\rho \mathrm{s}$ is the density of the solid. The resultant force along the slope, $\mathrm{f}_{2}=\mathrm{f}_{1} * \sin (\alpha)$. The net force along the slope, $\mathrm{f}_{3}=$ $\mathrm{f}_{2}-\mathrm{R}$, where $\mathrm{R}$ is resistance by water and bed. The acceleration of the movement (a) by the net force along the slope is: $a=f_{3} /\left(m^{*} g-b\right) / g=f_{3} /[m(1-\rho w / \rho s)]$. The travel distance $(\mathrm{s})$ in a time step $(\mathrm{t})$ if the initial velocity assumes zero: $\mathrm{s}=\mathrm{a} * \mathrm{t} * \mathrm{t} / 2=\mathrm{t}^{2} *$ $\mathrm{f}_{3} /[2 \mathrm{~m}(1-\rho \mathrm{w} / \rho \mathrm{s})]$. The horizontal moving distance in the Z-grid, $\mathrm{h}=\mathrm{s} * \cos (\alpha)$. The ratio of $\mathrm{h} / \mathrm{c}$ is proportional to the fraction of the materials moving from shoal cells toward center cells. Thus, the model is able to simulate an additional movement of solid particles along bed slopes. 
We compare DO simulation by the $13 \mathrm{k}$ calibration, the initial $57 \mathrm{k}$ model (Figure 1), and the improved 57k model with movement along slopes (Figure 4, presented later).

\subsection{Slope Setup in Grid Computation}

Slopes exist among all bed cells. We may simulate movement along slopes for all bottom cells. Alternatively, we may only consider significant slopes, such as across channels, since we mainly want to improve DO simulation in channel and slope is significant across channels. Correspondingly, there are two options to compute movement along slopes among bottom cells: 1) referencing all bottom cells and considering slopes between the reference cell and its adjacent cells; 2) referencing channel bottom cells and considering slopes to each reference cell from its shoal cells on two sides.

In the first option, for each reference cell (Table 1, column 1), there are maximum 4 adjacent cells (columns 2-5; zero cell number means the corresponding adjacent cell does not exist at grid boundary). A reference cell can either receive input from, or provide output to, its adjacent cells, depending on slope toward to or away from the cell. The computation of transport along slope between two cells loops all bottom cells (i.e., the reference cells) for four rounds for their four sides of adjacent cells. To avoid double counting, the transport between two cells is computed only when the reference cell receives input, while the associated adjacent cell reduces the same amount. The disadvantage of this option is that it needs to loop all bottom cells which prolongs computing time.

The second option does not consider all slopes in the model grid. We only reference channel cells (Table 2, Column 2; Column 1 is total shoal cells on one side from the channel cell). Then, we list the corresponding shoal cells, from deep to shallow for each side (Table 2, begin from Column 3). The cells one-by-one receive materials from its shallower adjacent ones. Since there are generally two shoal sides for a channel cell, therefore, a channel cell appears twice in Column 2, while the shoal cells only appear once. Note: if there are two dips in one transact, then they should be separated from the shallowest cell between the dips, and each dip cell is a reference cell.

Table 1. Bottom cell linkages for slope by referencing all bottom cells

\begin{tabular}{|l|l|l|l|l|}
\hline $\begin{array}{l}\text { Reference } \\
\text { cell }\end{array}$ & $\begin{array}{l}\text { Cell (left } \\
\text { adjacent) }\end{array}$ & $\begin{array}{l}\text { Cell (right } \\
\text { adjacent) }\end{array}$ & $\begin{array}{l}\text { Cell (upper } \\
\text { adjacent) }\end{array}$ & $\begin{array}{l}\text { Cell (lower } \\
\text { adjacent) }\end{array}$ \\
\hline 1 & 101 & 571 & 0 & 2 \\
\hline 2 & 102 & 572 & 1 & 3 \\
\hline.. & & & & \\
\hline.. & & & & $* * *$ \\
\hline 102 & $* * *$ & $* * *$ & $* * *$ & \\
\hline.. & & & & \\
\hline.. & & & & \\
\hline.. & & & & 11063 \\
\hline 11064 & 0 & 10002 & 1063 & 0 \\
\hline
\end{tabular}

Note: Numbers for the cells are not actual. 0 indicates no corresponding adjacent cell, due to the adjacent to grid boundary. 
Table 2. Bottom cell linkages for slope by referencing channel bottom cells

\begin{tabular}{|l|l|l|l|l|l|l|}
\hline $\begin{array}{l}\text { Total } \\
\text { side cells }\end{array}$ & $\begin{array}{l}\text { Reference } \\
\text { channel cell }\end{array}$ & \multicolumn{6}{|l|}{$\begin{array}{l}\text { Cells from channel to shoal (on either one } \\
\text { side) }\end{array}$} \\
\hline 4 & 201 & 410 & 511 & 620 & 721 & \\
\hline 2 & 201 & 121 & 98 & & & \\
\hline 5 & 232 & 440 & 541 & 649 & 751 & 862 \\
\hline 3 & 232 & 151 & 102 & 74 & & \\
\hline &.. & & & & & \\
\hline &.. & & & & & \\
\hline &.. & & & & & \\
\hline 3 & 999 & $* * *$ & $* * *$ & $* * *$ & & \\
\hline 5 & 999 & $* * *$ & $* * *$ & $* * *$ & $* * *$ & $* * *$ \\
\hline
\end{tabular}

Note: Numbers for the cells are not actual.

\subsection{Implementing Parallel Processing}

The Chesapeake Bay Water Quality Model parallel processing used domain decomposition for model cells. The decomposition is based on the numbers of total surface cell, total model cell, and total faces that connect cells, while does not specifically count channel cells and their shoal cells. Note: each bottom cell has a corresponding surface cell, therefore, bottom cells can be referred using surface cells. In this context, looping bottom cells in a decomposed domain can be expressed with looping surface cells.

In the first option of referencing cells in section 2.3, it is relatively easy to decompose the cells in Table 1 into domains, since it deals with all surface cells in the ordinary order. Therefore, it can use the general decomposition routine in the main program. However, because the surrounding 4 cells do not always split into a same domain, each of the four side cells needs to be handled separately to associate with the reference cells.

The second option of referencing cell focuses on channel cells and their shoal cells. This method saves computing time, but additional efforts and cautions are needed in domain decomposition, since the channel (referencing) cells are not specified in the main program's domain decomposition, and the lateral cells in one profile of a reference channel cell may be decomposed into different domains. A reference cell in a decomposed Table 2 may not necessarily be a channel cell, but should be the deepest cell among the cells in the decomposed profile in that domain.

\section{Results and Discussion}

\subsection{Comparing DO Simulations by Slope Movement and the Initial Model}

The plus symbols in Figure 4 represent the simulation of DO by the initial 57k grid model calibration, and the stars are the DO simulation after the implementation of the simulation of slope movement. The simulation of volatile solids' movement along the 
bottom slope yields lower DO (the star symbols) than the simulation by the initial 57K grid model (the plus symbols), and closer to the observed (the circle symbols). Consistently, the amounts of volatile solids in channel cells are higher in the revised $57 \mathrm{k}$ model than the initial $57 \mathrm{k}$ model. This supports the idea that the inability in the simulation of anoxia in the channel may be due in part to the lack of transport of volatile suspended sediments from the shallows to the channel, and that implementing movement of particulate organics along slopes can improve the simulation. In models of this type without an explicit simulation of resuspension and transport of particulate organics this approach may be important in order to represent the role of primary production and its fate [11].

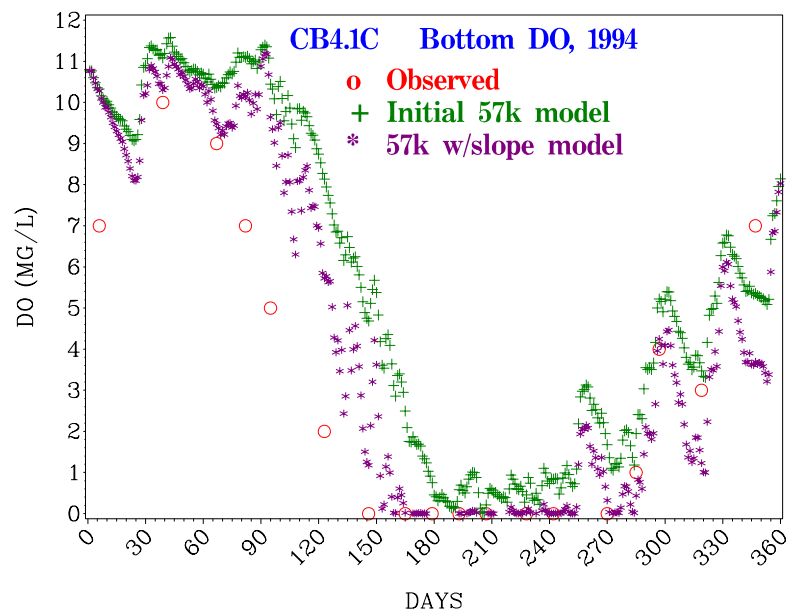

Fig. 4. DO simulation in $57 \mathrm{k}$ grid, before and after the simulation of slope movement

\subsection{Significance of Slope Movements along Axial versus Lateral Directions}

In option 2 of selecting cells we only reference channel bed cells and calculate the movement toward channel from the shoal in the lateral direction, but not the slope movement along the axial direction. This is based on the following two facts. A) The Bay's bathymetry shows that slope gradients are less significant along the axial direction than the lateral direction. B) The hourly hydrodynamic flow fields in the main stem bay and its tributaries indicate that the flow vectors along the channel axial direction are dominant, about 3 to 5 times the lateral direction, except during full high or low tide. Mass fluxes by currents are stronger along the axial direction than laterally. The lateral direction generally has weaker flow and steeper slopes than the axial direction, therefore, slope movement becomes importance in material movement in the lateral direction, while, material movement along the axial direction can be well simulated by water flow alone. 


\subsection{Exploring Other Factors Regulating Transport from Shoal to Channel}

The improvement of the DO simulation by slope movement in this paper is a preliminary study and further analysis is necessary. We can also explore other methods that may also promote drift of organic suspended solids to the channel, for example, adjustment of settling velocity.

A slower settling rate allows material to suspend at the water column for a longer time and have more horizontal movements before settling on the bed. If the dominant movement is toward the channel, then the channel may receive more volatile suspended solids under a slower settling than a faster settling rate. However, if the movement direction is dominantly unidirectional, the differences in material transport from the shoal to the channel between a slower settling and faster settling rate may be insignificant.

Ultimately a more sophisticated simulation of the resuspension of organic particulates from the bed and its subsequent transport is what's needed to more fully represent the movement of organic material from the shoals to the channel.

\section{Conclusion}

Besides movement due to hydrodynamic forces, in this simulation, particulate organic particles can settle down to the bed and move along the slope of the bed. This paper's approach in the simulation of organic particulate "focusing" to deep waters is important in the simulation of volatile suspended solid transport from shoal to channel, and for the simulation of anoxia and hypoxia in deep waters. The simulation of slope movement appears important in eutrophic simulations when the model does not adequately simulate the resuspension and transport of organic particles. Implementation of the slope movement for the Chesapeake Bay Estuarine Model significantly improves model simulations of summer anoxia.

\section{References}

1. Cerco, C.F., Cole, T.M.: Three-Dimensional Eutrophication Model of Chesapeake Bay. Technical Report EL-94-4, U.S. Army Engineer Waterways Experiment Station, Vicksbutg, MS, USA (1994)

2. D'Elia, C.F., Harding, L.W., Leffler, M., Mackiernan, G.B.: The role and control of nutrients in Chesapeake Bay. Water Sci. Tech. 26, 2635-2644 (1992)

3. Kemp, W.M., Boynton, W.R., Adolf, J.E., Boesch, D.F., Boicourt, W.C., Brush, G., Cornwell, J.C., Fisher, T.R., Gilbert, P.M., Hagy, J.D., Harding, L.W., Houde, E.D., Kimel, D.G., Miller, W.D., Newell, R.I.E., Roman, M.R., Smith, E.M., Stevenson, J.C.: Eutrophication of the Chesapeake Bay: Historic trends and ecological interactions. Marine Ecology Progress Series 303, 1-29 (2005)

4. Johnson, J.H., Kim, K.W., Heath, R.E., Hsieh, B.B., Butler, L.: Validation of a threedimensional hydrohynamic model of Chesapeake Bay. J. Hydr. Engrg., ASCE 199(1), $2-$ 20 (1993)

5. Postma, H.: Sediment transport and sedimentation in the estuarine environment. In: Lauff, G.H. (ed.) Estuaries, pp. 158-179. Am. Asso. Adv. Sci., Wash. (1967) 
6. Cerco, C.F., Noel, M.: The 2002 Chesapeake Bay Eutrophication Model, US Army Corps of Engineers, prepared for USEPA Chesapeake Bay Program. EPA-903-R-04-004 (2004)

7. CBPO Modeling Subcommittee: Chesapeake Bay Modeling Subcommittee April meeting (2008),

http: / / www. chesapeakebay.net/committee_msc_meetings.aspx

8. Johnson, J.H., Heath, R.E., Hsieh, B.B., Kim, K.W., Butler, L.: User's guide for a threedimensional numerical hydrodynamic, salinity, and temperature model of Chesapeake Bay, U.S. Army Engineer, Baltimore, MD, USA (1991)

9. Donaldson, C.: Atmospheric turbulence and the dispersal of atmospheric pollutants. In: Haugen, D.A. (ed.) Workshop on Micrometeorology, pp. 313-390. American Meteorological Society, Boston (1973)

10. Sheng, Y.P.: A three-dimensional mathematical model of coastal, estuarine and lake currents using boundary fitted grid, Report No. 585, A.R.A.P. Group of Titan systems, New Jersey, Princeton, NJ (1986)

11. Harding, L.W., Mallonee, M.E., Perry, E.S.: Toward a predictive understanding of primary productivity in a temperate partially stratified estuary. Estuar. Coastal Shelf Sci. 55, $437-$ $463(2002)$ 